\title{
Shadow Economy as a Self-Adjustment of Poverty and a Signal from Invisible Hand
}

\author{
Natalia Victorovna Kuznetsova ${ }^{1} \&$ Ekaterina Vasilievna Kuznetsova ${ }^{1}$ \\ ${ }^{1}$ Department of World Economy, School of Economics and Management, Far Eastern Federal University, \\ Vladivostok, Russia \\ Correspondence: Natalia Victorovna Kuznetsova, Department of World Economy, School of Economics and \\ Management, Far Eastern Federal University, Suhanova St. 8, 690950, Vladivostok, Russia. E-mail: \\ ipatovanat@mail.ru
}

Received: August 13, 2014 Accepted: November 6, 2014 Online Published: February 12, 2015

doi:10.5539/ass.v11n5p295 URL: http://dx.doi.org/10.5539/ass.v11n5p295

\begin{abstract}
The article determines the necessity to consider shadow economy as an indicator of required essential changes. Shadow economy serves as a methodological tool for evaluation of consumer needs and real potential of a national economy and business, as well as a tool that exposes underdeveloped national laws regulating economic activities. The latter is possible because built up layers of unnecessary laws that prevent business freedom, excessive interfering of government regulation with a national economy, and contradictory bureaucratic procedures impact developing of shadow economy. It was proved that one of the tools for overcoming shadow economy is the development of small business. As a rule, the reasoning behind operating business in the shadow sector involves inadequate obstacles on the way of entering legal and registered market, high taxes, and corruption. However, people have no protection, and their risks are too high in the shadow sector.
\end{abstract}

Keywords: shadow economy, governmental regulation, poverty, taxes, tax morale, cost, supply, demand

\section{Introduction}

Very often country's economy is perceived as an inheritably unstable, as if it has shortcomings that, by default, cannot be overcome. One of the oldest problems of the civilized society has been and still is one question: how to end world hunger and poverty. Modern society, as a rule, is divided into two types of people: those who consider distribution of poverty between different counties a great injustice, and those who accept this reality (as a rule those are trouble-free households) believing that this is a burden of the economy and there is nothing that can be done. But, as it has been offered by many specialists, there is a middle ground in these considerations.

Let us suggest three well-known postulates: economy is self-sufficient and requires substantial, but very minimal governmental control (ancient philosophy of economics); every human has the right for the pursuit of happiness (as democracy teaches us); unregistered economic activity is a signal for the government about the needs of an economy that naturally, if uninterrupted, strives to award smart production and distribution techniques that are adequate for existing demand and available resources - such formula changes welfare of many people towards a fair balance.

\section{Results}

In 1995 Peruvian economist Hernando de Soto presented his book "El OtroSendero" (The Other Path) in which he outlined results of a years-long research of unregistered economic activity in Lima, Peru by the Institute for Liberty and Democracy.

Hernando de Soto determines that because of the bureaucracy and adverse governmental strategy, that discouraged and prevented development of small business, people without initial assets and connections were forced to create business without registering it, creating a huge shadow sector in the economy of Peru.

Researchers from the Institute for Liberty and Democracy came to the conclusion that beginning with a mass migration of people from a countryside to the city (mostly because of the economic reasons), they never had a chance to evolve towards a better life because Peru's government created unreasonable barriers on the way of a small business. 
It was discovered that around $60-80 \%$ of Peru's population consisted of micro-entrepreneurs and small business owners (together with their families) who desired to live and work under the supremacy of law that protects the business from unfair practices. However, in the absence of relatable regulation people had to create their own rules of the game, thus giving a rise to economic and social revolution against legislative system that suppresses existence of small business (De Soto, 2002).

After realizing that such business generates a large part of Peru's economy and that it is not harmful by nature, the Institute developed an approach for the government to improve the situation based on the field research conducted among unregistered (shadow) entrepreneurs who could explain particular changes that needed to be done.

Before going forward it is crucial to point out that in this article term shadow economy is used to describe unregistered economic activity only and in no way covers economic activity that is illegal, i. e. activity that cannot be registered even in theory (illegal sale of weapons, trade in humans, etc.).

Almost two decades after "El OtroSendero," in their book "Poor Economics" (Banerjee \& Duflo, 2011) Abhijit Banerjee and Esther Duflo denied the idea about global strategies of development as a panacea for poverty. The authors carefully studied patterns of poverty in five continents and made a simple conclusion that small changes have significant results. They suggest that instead of focusing on general debates on how to end poverty, world hunger and illness, it is important to concentrate on specific solutions. On the top of relief from temporary foreign aid, in order to get people out of the poverty trap it is necessary to give those people independence by providing them with small investments.

Just as Hernando De Soto explained how important it is for lawmakers not to stand on the way of microbusiness, authors of "Poor Economics" point out another side of this medal - financial investments, the essence, however, is still the same. They describe phenomenon called microcredit and microfinancing that became relatively popular as an investment help for "barefoot entrepreneurs." It is important to take a notice that authors also point out that such form of aid will not solve all of the problems at once because microbusinesses do not always bring profit and stability, and break the cycle of poverty. There is always politics, corruption, and poor governmental institutions.

However, even considering challenges of forecasting of microfinancing's success as a universal remedy, it does work, and many charities keep investing money into education and small entrepreneurship. For example, Plan International uses model of Village Saving and Loans Association (VSL Associates, 2014) that involves sponsoring entrepreneurs from poor areas who do not have an opportunity to get a business loan from a standard financial institution. VSL model offers a self managed system where people can lend money, then invest back, and thus they end up lending money to a fellow community members. According to Plan International there are more than 60000 participants in more than 4000 groups, from which $78 \%$ of them are women (Plan International, 2014).

Reasons behind keeping the business in a "shadow," as a rule, lay in unrealistic barriers on the way of legal registration of the business, high taxes, and corruption. It is not true that people decide to stay in the "shadow" because it is easier and cheaper this way. In a shadow sector people have no insurance and security, the risks are too high just because the business is not registered properly and there is no guarantee for anything.

For example, in Turkey, the volume of the shadow economy turned out to be $66 \%$ from the official GDP in 2003 (36\% in 1985). In 2005, it was discovered than more than half of the workforce in Turkey is involved with unregistered economic activity. Experts explained it with unmanageable laws that regulate business activities and high taxes (Erdilek, 2007).

Let us introduce results of the research conducted by The World Bank, in the face of Friedrich Schneider, Andreas Buehn, and Claudio E. Montenegro. They estimated size of the shadow economy by county (162 countries) and year (from 1999 to 2007), based on Multiple Indicators Causes (MIMIC) model and other methods. In the Figure 1 we provided results for 2007 for selected countries (Schneider, Buehn, \& Montenegro, 2010).

Excessive regulation of official economy, bureaucracy, contradicting laws - all are the reasons behind development of a shadow economy. Countries that more than others have an excessive economic regulation also have larger sector of the shadow economy. For example, increase in governmental regulation index (ranging from 1 to 5) for one point leads to a 10 percent increase of shadow economy (Stigler, 1971). Severe restrictions appear to be a very strong stimulus for searching the alternative solutions, because they limit business freedom. 


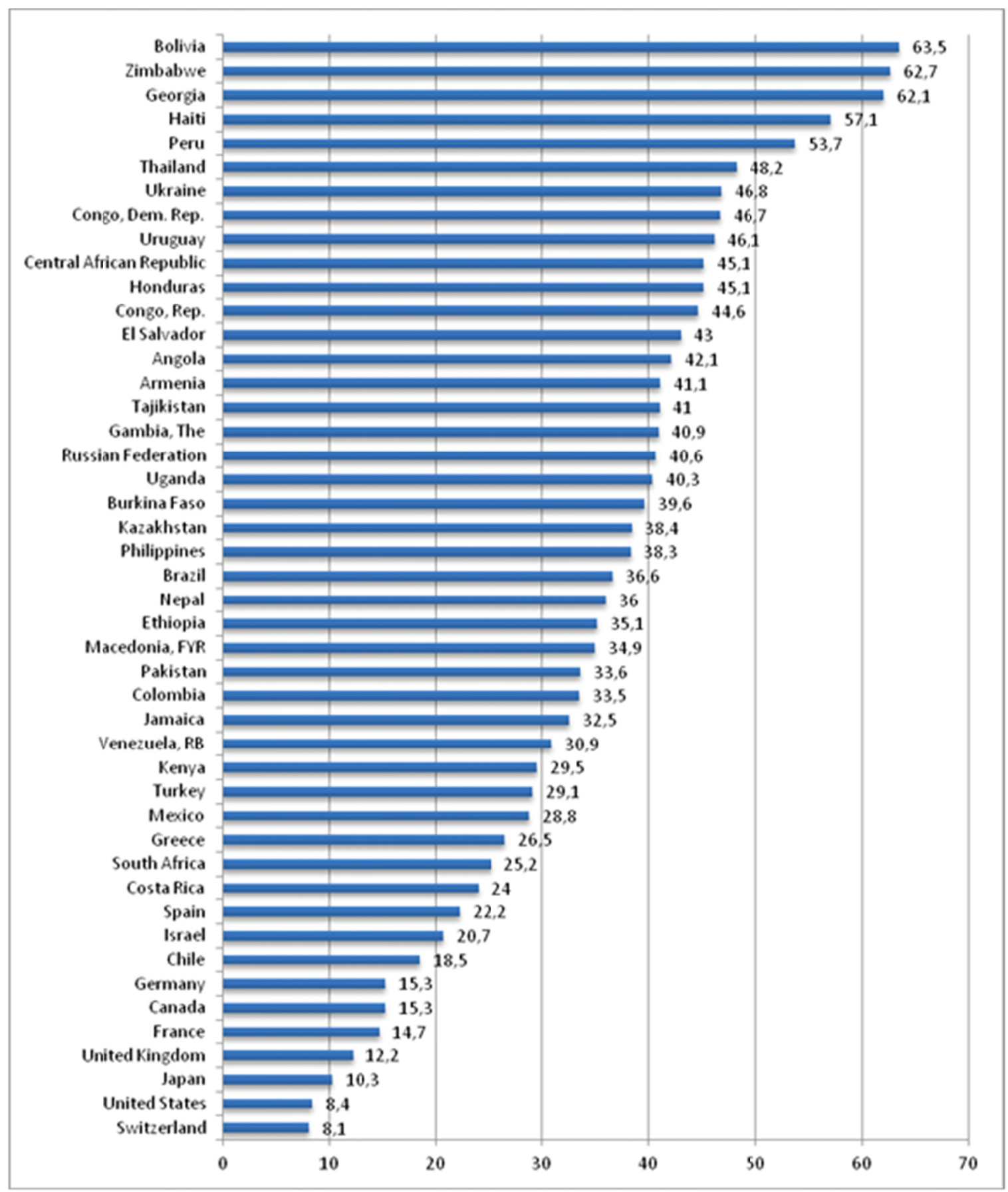

Figure 1. Shadow economy size by country for 2007

Let us bring the attention to some participant observations that many people might find familiar, thus proving the real volume and meaning of the shadow economy around us. Local phenomena called "Chinese markets" became extremely popular in Vladivostok, Russia (located closely to China) at the end of 1990. There, lower and middle class representatives, the majority at the time, would buy clothing and other retail. After the dissolution of Soviet Union, life in all the parts of Russia was very difficult, entrepreneurs used the opportunity and unethically manipulated prices for clothing. Those entrepreneurs who were more ethical could not sell clothing products cheaper than they did because of the cost of production and importation cost. So called "chelnokis" micro entrepreneurs who went to China or Chinese people themselves, bought cloth in China cheaper and brought it to unregistered markets in Vladivostok where it was sold to the majority of the residents. It was observed that, as a rule, those who could afford to buy cloth in more expensive areas preferred not to shop at the Chinese markets, however, those who would not be able to provide essential clothing to their children without 
such markets were the majority. Marketplaces like that existed in other cities as well, even in the capital Moscow (so called "Cherkizovskii" market). The value of such markets should not be underestimated especially in areas with higher poverty and limited access to basic needs. In severe economic conditions, consumer's demand is almost inelastic - many consumers simply have no other choice. When government began to shut down "Chinese markets" (though not forever because they still existed in one way or another), consumers had to switch to other places to shop, where in addition to paying higher prices for the same things they also had no choice but paying for the higher quality products they would not buy in other circumstances - they would rather choose to spend that money on food for example. Thus, buyers had to buy products at higher prices because of higher taxes, inefficient production, unreasonable choice of what product to import, and unethical manipulation of prices none of which customers had control of. In a situation like this, entrepreneurs have all the opportunity to impose their choice on the customer leading them into an economic trap.

The main point is that the invisible hand of economy gives signals to the product-makers, entrepreneur, and to the government what is affordable for the target market and what is not. The invisible hand rewards efficient decision-making because correct resource allocation and efficiency bring profit. There are always people with enough assets to be able to afford high quality products and luxury items, but those who cannot afford it will always shop at cheaper marketplaces. In undeveloped countries, those markets will be illegal, in developed countries they will be legal. Let us provide another participant observation. United Stated has been a home to two shopping chains - Macy's Inc. and Ross Stores, Inc. Macy's Inc. is a mid-range to upscale chain (mostly clothing) which customers are willing to pay for quality and a relative prestige. In fiscal 2012 Macy's Inc.'s sales were \$27.7 billion (Macy's Inc At-A-Glance, 2014). Ross Stores, Inc. operates the chain of stores where customers can get product with large discounts because the product (mostly clothing) either had lower quality or was out of fashion to be sold in more expensive stores. Ross Stores, Inc's stores made fiscal 2012 revenues of $\$ 9.7$ billion (Ross Dress For Less, 2014). In both cases the profit is made, which reveals that customers do make their choice accordingly with their financial situation, because the difference between two chains is obvious.

Going back to observations in Russia, in Moscow clothing is sold at an unreasonable price, and many people prefer to buy cloth abroad because not only it is cheaper but also the quality is better. Customers have a broad choice of websites (Retrieved April, 2014) that deliver any products that can be bought in another country through regular post office mail, avoiding customs in a way so they do not have to pay additional fees as merchandise, which are considered inadequate by many Russians, as well. Another way, learned through the field research, is to get products at lower prices (generally for luxury items) by finding a dealer who would buy a merchandise abroad, fly to the destination city where he or she is met by the customers, give them the merchandise, and then fly way (a dealer still makes profit). This example illustrates that if the system is not suitable for people they will find a way to fix it in their own way.

Examples like this can be found throughout the history. In early $1930^{\text {th }}$, in the midst of depression and long term preceding poverty and inequality of distribution of national wealth, workers in United States began to organize into self-help organizations. By 1934, teams of unemployed miners dug and sold 5 millions tons of "bootleg" coal below the commercial rate (HZinn, 2003).

From Great Depression's poverty struggles, to Peru's illegal settlements, to barefoot entrepreneurs of modern days - all of the unregistered economic activity (note, we did not describe any criminal activity) works as a social amortizator that in some cases helps to create and in other cases motivates the specific business that is essential for the economy.

In our opinion, activity like that must be studied as economic indicators of failing (or failed) development, because economics is a living science and it responds the needs of society - only in this case its development is adequate. Government has a significant part in this process. It can help in a great way. However, more often these days we observe that a government interferes the process either protecting special groups' interests or becomes Charles Dickens' circumlocution office that builds up barriers on the way of progress.

It is necessary to point out that governmental regulation of one field or another must emerge in response to the needs of consumers or producers that operate in that field. In this regard the theory of economic regulation can be divided into two parts: "public interest" theory according to which regulation is provided as a response to society's demands in order to improve inefficiency and injustice that take place at the market, and a "capture" theory according to which regulation is introduced in response to the demands of special interest groups that battle with each other in order to maximize their profit from participating in a group (Posner, 1974).

Thus, unregistered economic activity (in some countries - illegal) must serve as an indicator of needed changes. From bootlegging in America, to the illegal sale of shoes in Soviet Union, to cocaine farmers in Colombia - all 
of these are either red flags for the changes that need to be made or indicators of past mistakes that were not corrected and that the blindness of the government led the economy into such deadend.

Inadequate perception of poverty, consumption, and consumer choice lead to the formation of economic activity beyond official regulation, thus not being part of this economy, which itself is an absurd because any economy cannot be divided into separate unrelatable entities. Self-sustainability of economy is natural and it comes when it rewards those who use given resources most efficiently. It is necessary to have a natural proactive amortization that should not be fought, but instead adjusted as we would adjust supply to a changed demand.

Unregistered economy should serve as a methodological tool for evaluation of real capabilities of economy and business, consumer needs, tool for adjustment of laws that regulate economic activity, and social responsibility of existing businesses. "The invisible hand takes all the information about buyers and sellers into account and guides everyone in the market to the best outcome as judged by the standard of economic efficiency." (Mankiw, 2008)

There must be a benefit for a consumer from his or her participation in the market, just as for the seller. Natural market does not revolve around profit of only one of the participants. Such balance between consumer's benefit and seller's profit is reached by efficient allocation of resources. If actors involved in a formation of the products can allocate resources efficiently they become winners of the market who, just as the law of the jungle suggests, survives.

Equilibrium, found on the supply and demand curve, is an invisible hand of the market. It serves as an indicator that shows that all the resources, not only producer's ones, but also customer's (money that he or she pays), are allocated in the most efficient way.

Price would be the most important indicator of economic and business decisions, efficiency of production and allocation of resources. Consumer's choice shows, first of all, an optimal balance between limitation of a household's budget and desire to buy nonessential goods that only particular household's budget can afford.

If illegal markets with different pricing policy start emerging on the country's economic arena it should be considered as an indicator for the market to be in an artificial, unhealthy condition. This proves the shadow economy must not be perceived only as a negative phenomenon; mostly it serves as a signal that the strategy chosen by government is failing or has significant imperfections.

Research shows that development of shadow economy is mostly influenced by: high taxes and social security contributions (around $45-52 \%, 22-25 \%$ out of which may fall into a poor tax morale - especially if citizens do not get adequate public services in return for their taxes); low quality of state institutions, corruption and bureaucracy (10-17\%); high level of labor market regulation - governmental interference, anything that limits business freedom (7-9\%) (Schneider \& Williams, 2013).

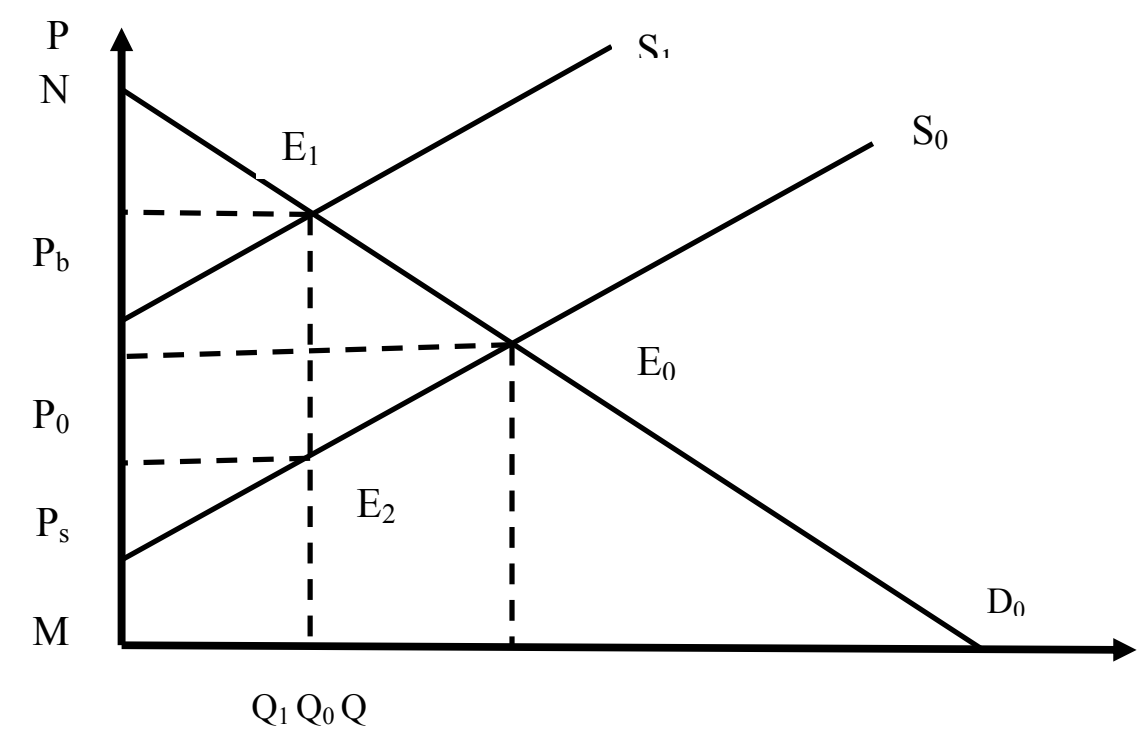

Figure 2. Impact of an imposed tax on shadow economy 
Let us analyze influence of tax on size of the shadow economy. Let us suggest that the government imposed tax for a product unit on makers of product. The key role in the distribution of the tax burden will be played by elasticity of supply and demand curves. Impementation of such tax will increase producers' costs, and accordingly supply curve will move from $\mathrm{S}_{0}$ to $\mathrm{S}_{1}$ (see Figure 2). As the result equilibrium price rises (from $\mathrm{P}_{0}$ to $\mathrm{P}_{\mathrm{b}}$ ). In addition equilibrium quantity of the product decreases (from $\mathrm{Q}_{0}$ to $\mathrm{Q}_{1}$ ). As a result, consumers surplus decreases from the area of $\mathrm{NP}_{0} \mathrm{E}_{0}$ triangle to an area of $\mathrm{NP}_{\mathrm{b}} \mathrm{E}_{1}$ triangle. In the same time, producers surplus decreases from area $\mathrm{MP}_{0} \mathrm{E}_{0}$ to $\mathrm{MP}_{\mathrm{S}} \mathrm{E}_{2}$.

Thus, actual prize, that producer receives for his or her product decreases as well as volume of products sold. So then, because of the tax, consumers' losses compose area of trapezium $\mathrm{P}_{\mathrm{b}} \mathrm{P}_{0} \mathrm{E}_{0} \mathrm{E}_{1}$, and producers' losses - area of $\mathrm{P}_{\mathrm{S}} \mathrm{P}_{0} \mathrm{E}_{0} \mathrm{E}_{2}$. Part of those losses was transferred to a government in a form of an aggregate tax burden (area of rectangle $\mathrm{P}_{\mathrm{S}} \mathrm{E}_{2} \mathrm{E}_{1} \mathrm{P}_{\mathrm{b}}$ ). Part of producers' and consumers' tax losses (area of triangle $\mathrm{E}_{1} \mathrm{E}_{2} \mathrm{E}_{0}$ ) was not transferred to anybody (these are deadweight losses). Point $\mathrm{E}_{0}$ is Pareto-efficient, therefore, neither producer nor customer would not want to abandon this balance. Given price satisfies all the participants of the market.

However, in the result of the implementation of a tax equilibrium volume of product sold on the market decreases, which in its turn entails decline in welfare of consumers, producers, and society as a whole. Whereby government will collect tax in a size of area of rectangle $\mathrm{P}_{\mathrm{S}} \mathrm{E}_{2} \mathrm{E}_{1} \mathrm{P}_{\mathrm{b}}$.

But the volume of goods $\left(\mathrm{Q}_{0}-\mathrm{Q}_{1}\right)$ will be produced, because the value of those goods for consumers is higher that production cost of those goods for producers. In this case, size of the shadow market will be calculated as a multiplication $\left(\mathrm{Q}_{0}-\mathrm{Q}_{1}\right)$ by price of a product. Depending on risks and fees for tax evasion (for unit of a product), price will not be higher $P_{b}$, but not lower than $P_{S}$. In the case, of perfect price discrimination, deadweight losses seize to exist, size of triangle $\mathrm{E}_{1} \mathrm{E}_{2} \mathrm{E}_{0}$ will be transferred to a producer in the form of part of earnings.

Thus, size of the shadow economy is determined by the size of producer's earnings (that directly depends on the price of the product). In the case of perfect price discrimination size of shadow economy is equal to rectangle $\mathrm{Q}_{1} \mathrm{E}_{1} \mathrm{E}_{0} \mathrm{Q}_{0}$. If perfect price discrimination is not applied, size of shadow economy shrinks and customers get an additional consumer surplus. Therefore, tax imposure on a product unit does not lead to deadweight loss, but leads to shadow economic activity. Size of the shadow economy in this case relates also to the size of the tax for a product unit.

\section{Discussion}

It is widely accepted that one of the main reasons behind shadow economy is a burden of tax, that includes social payments (Lippert \& Walker, 1997; Schneider, 2003, Tanzi, 1999; Giles, et al., 2002). Johnson, et al. theoretically explained and empirically showed the connection between the level of regulation and share of shadow economy (Johnson et al., 1998). The tax rate itself does not influence concealment of economic activity and profit, but inefficient taxation system does. If income tax rate grows in countries with well-developed governmental institutions the shadow economy will not grow (Friedman et al., 2000). Attention is also drawn to the tax morale that shows general people's attitudes towards illegality and transferring their activities into shadow sector (Schneider \& Klinglmair, 2004). The conclusion is made about a very strong negative correlation: higher inclination towards fulfillment of tax obligations decreases shadow economy (Torgler \& Schneider, 2007).

M. Allingham and A. Sandmo (1972) examined taxpayer's choice model - when a taxpayer determines what amount of his or her income will be hidden from the government depending on the tax rate and likelihood of receiving a fine. They showed that shadow economy and taxes are not always directly interdependent: on one hand, the tax increase motivates the desire to go "shadow," on the other hand - decreases real income of the population which in its term increases nonacceptance of risks, and people start being afraid of hiding their income. C. Clotfelter (1983), found some connection between one's inclination to go "shadow" and the source of his or her income. H. Watson (1985) divides economy in two sectors, one in which tax evasion is possible and in another tax evasion is not possible.

Another reason of shadow economy growth is an intensified governmental regulation activity and shortcomings of institutional systems. Schneider (2000) demonstrated that it is the strengthening of the tax burden and governmental regulation that explains increased shadow economy in 18 countries of OECD in the timeframe between 1960 and 1998.

Dreher and Schneider proved that stiffening of regulation leads to increase of the shadow economy, however increase of the shadow economy strengthens it in economies of low income (Dreher \& Schneider, 2006). De 
Soto came to conclusion that shadow economy is people's reaction to a system that forces them into position of victims of legal and economic mayhem (De Soto, 2002).

D. Cassel and U. Cichy thought that the common factor is an economic system applied by the government, strategical nature of regulation of distribution relationship. As for specific economic reasons, they differ: in the West it is strengthening of the taxation system, in the East - inflation. Those are the root reasons that motivate shadow economy growth and determine proportions of shadow and official economies (Cassel \& Cichy, 1987).

\section{Conclusions}

The government should observe the changes of the dynamics of the shadow operations, a tool for adjusting the laws regulating economic activity, especially it is necessary for operative measures in the intervention of the regulation of small business. As the instruments of protection for small business it is obvious to use a tax rate, which is in a well-developed public institutions will constrain the shadow economy. As the investment support it should be developed the micro-credit and micro-finance measures. It will help to alleviate the barriers in the development of small businesses.

In their quest of finding an answer to the question - why nations fail, Acemoglu and Robinson came up with an interesting point that "while economic institutions are critical for determining whether a country is poor or prosperous, it is politics and political institutions that determine what economic institutions a country has" (Robinson \& Acemoglu, 2012).

Hernando De Soto and the Institute for Liberty and Democracy revealed innovational meaning of the shadow economy, its role in the formation of new socio-economic institutions, once again, as many economists before and after, pointed out economy's ability for self-organization anself sustainability. However, it is not unusual to ignore economy's ability to create perfect markets without governmental intervention. Among all, shadow economy serves as an "economic leveling" (smoothing off fluctuations in economic conjuncture with the help of movement of resources between legal and shadow markets), as a "social amortization" (preventing unwanted social consequences), and as a "built-in stabilizer" (when shadow economy feeds legal economic activity).

\section{References}

Acemoglu, D., \& Robinson, J. (2012). Why nations fail: The origins of power, prosperity, and poverty (p. 571). Crown Business, New York.

Allingham, M. G., \& Sandmo, A. (1972). Income Tax Evasion: A Theoretical Analysis. Journal of Public Economics, 1(3-4), 323-338. http://dx.doi.org/10.1016/0047-2727(72)90010-2

Banerjee, A., \& Duflo, E. (2011). Poor Economics: A Radical Rethinking of the Way to Fight Global Poverty (p. 320). Public Affairs.

Cassel, D., \& Cichy, U. (1987). The Shadow Economy and Economic Policy in East and West: A Comparative System Approach. In S. Alessandrini, \& B. Dallago (Eds.), The Unofficial Economy. Consequences and Perspectives in Different Economic Systems (pp. 127-144). Gower.

Clotfelter, C. T. (1983). Tax Evasion and Tax Rates: An Analysis of Individual Returns. Review of Economics and Statistics, 65(3), 363-373. http://dx.doi.org/10.2307/1924181

De Soto, H. (2002). The Other Path: The Economic Answer to Terrorism (p. 273). Basic Books.

Dreher, A., \& Schneider, F. (2006). Corruption and Shadow Economy: An Empirical Analysis. Institute for the Study of Labor Discussion. Paper \# 1936.

Erdilek, A. (2007). Turkey's Unregistered Economy. In Today's Zaman. Retrieved February 19, 2014, from http://www.todayszaman.com/columnistDetail_getNewsById.action?newsId=103210

Friedman, E., Johnson, S. Kaufmann, D., \& Zoido-Lobaton, P. (2000). Dodging the grabbing hand: The determinants of unofficial activity in 69 countries. Journal of Public Economics, 76(6), 459-493. http://dx.doi.org/10.1016/S0047-2727(99)00093-6

Giles, D., \& Tedds, L. M. (2002). Taxes and the Canadian Underground Economy. Canadian Tax Paper \# 106, Canadian Tax Foundation, Toronto/Ontario.

Johnson, S., Kaufmann, D., \& Zoido-Lobaton, P. (1998). Regulatory discretion and the unofficial economy. The American Economic Review, 88(2), 387-392.

Lippert, O., \& Walker, M. (Eds.). (1997). Underground Economy: Global evidences of its size and impact (p. 328). The Frazer Institute, Vancouver. 
Macy's Inc At-A-Glance. (2014). Retrieved April 19, 2013, from http://www.macysinc.com/for-investors/ata-glance/default.aspx

Mankiw, N. G. (2008). Principles of Microeconomics (5th ed., p. 545). Cengage Learning.

Plan International. (2014). Retrieved April 16, 2014, from https://plan-international.org/where-we-work/africa/ egypt/what-we-do/village-saving-and-loans-association-vsla-programme

Posner, R. A. (1974). Theories of Economic Regulation. The Bell Journal of Economics and Management Science, 5(2), 335-358. http://dx.doi.org/10.2307/3003113

Ross Dress For Less. (2014). Retrieved April 19, 2014, from http://phx.corporate-ir.net/phoenix.zhtml?c= 64847\&p=irol-IRHome

Schneider, F. (2000). The Increase of the Size of the Shadow Economy of 18 OECD Countries: Some Preliminary Explanations. Paper presented at the Annual Public Choice Meeting, March 10-12, Charleston, S.C.

Schneider, F. (2003). The Shadow Economy. In C. K. Rowley, \& F. Schneider (Eds.), Encyclopedia of Public Choice (pp. 1-9). Dordrecht: Kluwer Academic Publishers. http://dx.doi.org/10.1017/CBO9780511493591

Schneider, F., \& Klinglmair, R. (2004). Shadow Economies around the World: What Do We Know? Institute for the Study of Labor. Department of Economics, Johannes Kepler University Linz, Austria. Discussion Paper \# 1043.

Schneider, F., \& Williams, C. C. (2013). The Shadow Economy (p. 183). The Institute of Economic Affairs. London. http://dx.doi.org/10.1017/CBO9781139542289

Schneider, F., Buehn, A., \& Montenegro, C. E. (2010). Shadow Economy All Over the World: New Estimates for 162 Countries from 1999 to 2007 (pp. 45-47). Policy Research Working Paper 5356. The World Bank Development Research Group Poverty and Inequality Team and Europe and Central Asia Region Human Development Economics Unit.

Stigler, J. (1971). The Theory of Economic Regulation. The Bell Journal of Economics and Management Science, 2(1), 3-21.http://dx.doi.org/10.2307/3003114

Tanzi, V. (1999). Uses and Abuses of Estimates of the Underground Economy. The Economic Journal, 109(456), 338-340. http://dx.doi.org/10.1111/1468-0297.00437

Torgler, B., \& Schneider, F. (2007). Shadow Economy, Tax Morale, Governance and Institutional Quality: A Panel Analysis. Institute for the Study of Labor Discussion Paper \# 2563.

VSL Associates. (2014). Retrieved April 19, 2014, from http://vsla.net/

Watson, H. (1985). Tax Evasion and Labor Markets. Journal of Public Economics, 27(2), 231-246. http://dx.doi.org/10.1016/0047-2727(85)90048-9

Zinn, H. (2003). A People's History of the United States (p. 395). Harper Perennial, New York.

\section{Copyrights}

Copyright for this article is retained by the author(s), with first publication rights granted to the journal.

This is an open-access article distributed under the terms and conditions of the Creative Commons Attribution license (http://creativecommons.org/licenses/by/3.0/). 